\title{
Kebijakan Penal Mengenai Kriminalisasi Di Bidang Keuangan
}

\author{
Salman Luthan \\ Fakultas Hukum Universitas Islam Indonesia \\ Jl. Tamansiswa No. 158 Yogyakarta \\ sl_luthan@yahoo.com
}

\begin{abstract}
Research of penal policy on criminalization in financial affairs discusses two main problems: regulating policy on criminal offences, and regulating policy on criminal sanction for financial offences. The regulating policy on criminal offences shows an increase of various conducts that have been criminalized by legislator as a consequence of social change, economic and trade globalization, as well as technological development. Justification of criminalization base on liberal individualiatic theory and political affairs (ordening strafrect theory). The regulating policy on criminal sanction tends to strengthen criminal sanction of offences in financial affairs as a response to the weakness of law enforcement, as an effort to reform financial institutions, as a implementation of penal philoshophy of deterrence, and as a high "spirit" of legislators to punish the offenders.
\end{abstract}

Key Words: penal policy, criminalization, finance

\begin{abstract}
Abstrak
Ada dua permasalah yang dibahas dalam penelitian tentang kebijakan penal untuk kejahatan dalam bidang keuangan, yaitu: penyesuaian kebijakan berkaitan dengan tindak pidana dan penyesuaian kebijakan terkait sanksi pidana bagi pelanggaran bidang keuangan. Penyesuaian kebijakan terkait dengan tindak pidana menunjukkan adanya peningkatan pada perilaku yang dianggap sebagai kejahatan oleh para pembuat undang-undang akibat perubahan sosial, ekonomi, perdagangan global, dan juga perkembangan teknologi. Penyesuaian ini didasarkan pada Teori Individual Liberal dan urusan politik (Ordening Strafect Theory ). Penyesuaian kebijakan terhadap sanksi pidana cenderung memperkuat sanksi pidana terhadap pelanggaran dalam bidang keuangan. Hal ini merupakan respon terhadap lemahnya penegakan hukum, dan juga usaha untuk mereformasi lembaga keuangan, serta sebagai implementasi falsafah hukum pencegahan, dan penyemangat bagi pembuat undang-undang untuk menghukum mereka yang bersalah.
\end{abstract}

Kata kunci : kebijakan penal, kriminalisasi, keuangan 


\section{Pendahuluan}

Penelitian ini dilatarbelakangi oleh empat pertimbangan; Pertama, proses kriminalisasi terus berlangsung dalam hukum kita yang ditandai dengan adanya tindak pidana baru di bidang keuangan. Misalnya, tindak pidana pencucian uang yang diatur dalam UU Nomor 15 Tahun 2002 tentang Tindak Pidana Pencucian Uang sebagaimana diubah dengan UU Nomor 25 Tahun 2003.

Kedua, perubahan undang-undang di bidang keuangan dalam dua dekade terakhir berjalan relatif cepat. Misalnya, UU Nomor 9 Tahun 1994 tentang Ketentuan Umum Dan Tata Cara Perpajakan diubah dengan UU Nomor 16 Tahun 2000, dan UU Nomor 7 Tahun 1992 tentang Perbankan diubah dengan UU Nomor 10 Tahun 1998, dan UU Nomor 15 Tahun 2002 tentang Tindak Pidana Pencucian Uang diubah dengan UU Nomor 25 Tahun 2003. Apakah perubahan undang-undang tersebut membawa dampak terhadap perluasan tindak pidana?

Ketiga, adanya fragmentasi dalam penentuan berat ringannya sanksi pidana yang diancamkan terhadap tindak pidana di bidang keuangan. Fragmentasi penentuan berat ringan sanksi pidana tersebut dapat dilihat dari adanya perbedaan klasifikasi gradasi keseriusan tindak pidana yang cukup tajam antara jenis tindak pidana yang satu dengan tindak pidana yang lain dalam satu rumpun delik. ${ }^{1}$ Di samping itu, ada fragmentasi yang tajam dalam penentuan sanksi pidana antara berbagai undangundang. Misalnya, perbedaan sanksi tindak bagi tindak pidana pajak dan sanksi pidana bagi tindak pidana perbankan.

Keempat, adanya kesenjangan pemikiran antara pemikiran yang berkembang dalam RUU KUHP dengan pemikiran yang dirumuskan dalam berbagai undangundang di Bidang Keuangan. Kesenjangan pemikiran itu berkaitan dengan konsep sanksi pidana, khususnya mengenai pengaturan sanksi pidana bagi korporasi dan sanksi pidana denda. ${ }^{2}$

Kajian terhadap Kebijakan Penal Mengenai Kriminalisasi di Bidang Keuangan mempunyai arti penting untuk mengevaluasi kebijakan legislatif mengenai kriminalisasi di bidang keuangan yang berlangsung selama ini. Melalui kajian tersebut akan diketahui apakah hukum pidana dan sanksi pidana digunakan secara

\footnotetext{
${ }^{1}$ Salman Luthan, "Kebijakan Legislatif Mengenai Kriminalisasi dalam Perundang-undangan Pidana”, Tesis S2, UI, Jakarta, 1998, hlm. 270-271.

${ }^{2}$ Mardjono Reksodiputro, "Catatan-Catatan Sekilas Tentang Bab Pemidanaan, Pidana dan Tindakan (Bab III - Buku Kesatu)”, Rancangan Undang-Undang Republik Indonesia Tentang KUHP.
} 
proporsional sesuai dengan kaidah-kaidah akademik dan kaidah-kaidah kebijakan hukum pidana atau justeru malah sebaliknya.

Dasar pembenaran kriminalisasi yang digunakan di dalam kerangka pemikiran ini adalah kombinasi antara teori liberal individualistik dan teori ordenings strafrecht. Teori liberal individualistik bertitik tolak dari prinsip kerugian yang merujuk kepada pemikiran John Stuart Mill yang dirumuskan dalam bukunya On Liberty:" The only purpose for which power can be rightfully exercised over any member of civilised society, against his will, is to prevent harm to others. His own good, either physical or moral, is not a sufficient warrant."3

Pernyataan Mill tersebut menegaskan bahwa kekuasaan negara untuk mengatur masyarakat dibatasi oleh kebebasan warganegara. Negara hanya boleh campur tangan terhadap kehidupan pribadi seorang warganegara bila warganegara tersebut merugikan orang lain. Jika tindakan seseorang tidak merugikan orang lain, maka tidak boleh ada pembatasan terhadap kebebasannya.

Prinsip tidak merugikan orang lain merupakan prinsip pembatas campur tangan negara terhadap kehidupan pribadi warganegara, yang sering juga disebut sebagai prinsip Mill. Dalam falsafah Mill, manusia adalah makhluk otonom yang mempunyai hak penuh untuk menentukan kehidupan pribadinya. Kebebasan individu tidak boleh dibatasi oleh negara sepanjang individu yang bersangkutan tidak merugikan individu lainnya.

Norval Morris dan Gordon Howkins menerjemahkan ungkapan Mill dalam konteks hukum pidana dengan mengatakan bahwa "hukum pidana tidak dapat mencabut hak seseorang untuk pergi ke neraka menurut caranya sendiri, asalkan dia tidak secara langsung merugikan orang lain atau harta benda orang lain. Suatu perbuatan dikriminalisasi karena perbuatan itu merugikan orang lain ${ }^{4}$

Sedangkan menurut teori "ordenings strafrecht", sebagaimana dikemukakan oleh Roling dan Jesseren d'Oliveira Prakken, hukum pidana adalah alat atau instrumen kebijakan pemerintah. ${ }^{5}$ Penggunaan hukum pidana sebagai instrumen kebijakan pemerintah merupakan kecenderungan baru dalam perkembangan hukum pidana modern. ${ }^{6}$

\footnotetext{
${ }^{3}$ John Stuart Mill, On Liberty, 1974, bab 1 paragraf 9.

${ }^{4}$ Sue Titus Reid, mengutip Norvall Morris dan Gordon Hawkins dalam Criminal Law, Third Edition, Englewood Cliffs, New Jersey, Prentice Hall, hlm. 12

${ }^{5}$ Roeslan Saleh, Beberapa Asas Hukum Pidana Dalam Perspektif, Jakarta, Aksara Baru, 1983, hlm. 52.

${ }^{6}$ Roeslan Saleh, "Kebijakan Kriminalisasi Dan Dekriminalisasi: Apa Yang Dibicarakan Sosiologi Hukum Dalam Pembaruan Hukum Pidana Indonesia”, 1993, hlm. 5.
} 
Penetapan kriminalisasi menurut ordenings strafrecht, "bukanlah apa yang dipandang oleh masyarakat sebagai "tindak hukum" yang ditunjuk sebagai perbuatan pidana, melainkan apa yang bertentangan dengan kebijakan pemerintah. Dengan kata lain, suatu perbuatan dikriminalisasi karena perbuatan itu bertentangan dengan kebijakan pemerintah" ${ }^{7}$

Mengkombinasikan tesis pokok teori liberal individualistik dan teori ordening strafrecht, dapat dikemukakan bahwa suatu perbuatan di bidang keuangan dikriminalisasi bukan hanya karena perbuatan itu merugikan orang lain, tapi juga karena perbuatan itu bertentangan dengan kebijakan pemerintah.

Adapun kerangka pemikiran yang digunakan untuk menganalisis kebijakan pengaturan sanksi pidana bagi tindak pidana di bidang keuangan adalah kombinasi antara teori penangkalan (deterrence) dan teori retribusi (retribution), khususnya prinsip proporsionalitas ordinal (ordinal principle) dan prinsip proporsionalitas kardinal (cardinal principle). Teori penangkalan mempunyai tiga asumsi, yaitu:

1. Pembentuk undang-undang menganggap setiap manusia adalah makhluk ekonomis rasional yang selalu menggunakan kalkulasi untung rugi dalam melakukan suatu perbuatan, termasuk dalam melakukan kejahatan. ${ }^{8}$

2. Tujuan pemidanaan adalah untuk menangkal seorang terpidana melakukan kejahatan kembali (recidivisme) dan mencegah masyarakat umum melakukan hal yang sama. ${ }^{9}$

3. Penentuan berat ringan sanksi pidana berlandaskan kepada prinsip bahwa gradasi hukuman melebihi gradasi keseriusan tindak pidana. Artinya, kalkulasi kerugian (hukuman/penderitaan) yang diperoleh akibat melakukan tindak pidana lebih besar daripada keuntungan (harta benda/kesenangan) yang didapat dari kejahatan.

Meskipun prinsip penentuan berat ringan sanksi pidana menurut teori penangkalan berlandaskan kepada prinsip bahwa gradasi hukuman melebihi gradasi keseriusan tindak pidana, tapi penyusunan gradasi berat ringan sanksi pidana harus tetap mengacu kepada asas proporsionalitas, baik proporsionalitas cardinal maupun proporsionalitas ordinal.

Proporsionalitas cardinal (cardinal proporsionality) mengasumsikan bahwa semua tingkat skala hukuman, hukuman maksimum dan jarak hukuman nyata, harus proporsional terhadap besarnya serangan perbuatan. Secara nyata apakah tingkat itu harus ada dalam suatu negara tertentu adalah suatu masalah untuk

\footnotetext{
${ }^{7}$ Ibid.

${ }^{8}$ C.M.V. Clarkson, Understanding Criminal Law, Second Edition, London, Suveet and Maxwell, 1998, hlm. 219.

${ }^{9}$ Ibid., hlm. 216-217.
} 
diperdebatkan, didasarkan atas penelitian kriminologis dan, dengan tidak dapat dielakkan, dibatasi oleh konvensi-konvensi sosial.

Proporsionalitas ordinal (ordinal proporsionality) yang memperhatikan berapa suatu kejahatan harus dihukum diperbandingkan dengan tindak pidana yang mirip, dan diperbandingkan terhadap karakter lebih atau kurang serius dari kejahatan lain. Tetapi konsep proporsionalitas membutuhkan pemeliharaan suatu hubungan antara keseriusan kejahatan yang relatif dengan kekerasan hukuman yang relatif. ${ }^{10}$

\section{Rumusan Masalah}

Adapun permasalahan dalam penelitian ini meliputi: (a) bagaimanakah kebijakan pengaturan tindak pidana dalam undang-undang di bidang keuangan sejak 1992 sampai sekarang?, dan (b) bagaimanakah kebijakan pengaturan sanksi pidana bagi tindak pidana di bidang keuangan sejak 1992 sampai sekarang?

\section{Tujuan Penelitian}

Adapun tujuan dari penelitian ini untuk mengetahui: (a) kebijakan pengaturan tindak pidana dalam undang-undang di bidang keuangan sejak 1992 sampai sekarang, dan (b) kebijakan pengaturan sanksi pidana bagi tindak pidana di bidang keuangan sejak 1992 sampai sekarang.

\section{Metode Penelitian}

Penelitian ini merupakan penelitian hukum normatif, yaitu penelitian yang menggunakan norma-norma yang ada dalam undang-undang. ${ }^{11}$ Pertimbangan memilih jenis penelitian tersebut karena bahan utama penelitian adalah undangundang di bidang keuangan (UU Perbankan, UU Ketentuan Umum dan Tata Cara Perpajakan, dan UU Pasar Modal, dan UU Tindak Pidana Pencucian Uang), rancangan undang-undang, risalah pembentukan undang-undang, dan literatur.

Data penelitian dikumpulkan terutama melalui studi dokumen, sedangkan wawancara dengan anggota DPR yang terlibat dalam pembentukan undang-undang

${ }^{10}$ Ibid., hlm. 12.

${ }^{11}$ Soerjono Soekanto dan Sri Mamudji, Penelitian Hukum Normatif, Cetakan ketujuh, Jakarta, PT Raja Grafindo Persada, 2003, hlm. 11-13. 
di bidang keuangan sebagai nara sumber berfungsi sebagai pelangkap bagi data hasil studi dokumen.

Kerangka analisis yang digunakan dalam penelitian ini adalah analisis kualitatif, yaitu analisis yang menguraikan data penelitian menjadi komponen-komponen melalui rangkaian kata-kata dan atau gambar. Analisis kualitatif lebih menekankan analisis terhadap kualitas data daripada kuantitas data itu sendiri untuk mengungkapkan karakternya yang khas, pengertiannya, konteks sosialnya, dan relasinya satu sama lain melalui deskripsi dan interpretasi.

\section{Hasil Penelitian dan Analisis}

\section{a. Perkembangan Perumusan Tindak Pidana Di Bidang Keuangan}

Perkembangan pengaturan tindak pidana di bidang keuangan (tindak pidana perbankan, tindak pidana pajak, tindak pidana pasar modal, dan tindak pidana pencucian uang) menunjukkan adanya peningkatan kuantitas tindak pidana (perbuatan yang dikriminalisasi) sejak tahun 1992 sampai sekarang. Peningkatan kuantitas tindak pidana dilakukan melalui pembentukan undang-undang baru dan perubahan undang-undang yang sudah ada. ${ }^{12}$

Dalam pembentukan UU Nomor 15 Tahun 2002 Tentang Tindak Pidana Pencucian Uang dikriminalisasi 18 perbuatan menjadi tindak pidana pencucian uang yang dirumuskan dalam Pasal 3, Pasal 6, Pasal 8, dan Pasal 10 undang-undang terebut. Artinya, ada penambahan 18 jenis tindak pidana pencucian uang ke dalam kelompok tindak pidana di bidang keuangan. Kemudian dalam perubahan UU Nomor 15 Tahun 2002 dengan UU Nomor 25 Tahun 2003 terdapat 4 perbuatan yang dikriminalisasi menjadi tindak pidana pencucian uang oleh pembentukan undang-undang.

Peningkatan jumlah tindak pidana di bidang keuangan juga terjadi melalui penggantian dan perubahan UU Perbankan. Dalam UU Nomor 14 Tahun 1967 Tentang Pokok-Pokok Perbankan hanya ada 4 jenis tindak pidana perbankan, namun dalam UU Nomor 7 Tahun 1992 tentang Perbankan, pengganti UU Nomor 14 Tahun 1967, terdapat 8 jenis perbuatan yang dikriminalisasikan menjadi tindak pidana

\footnotetext{
${ }^{12}$ Untuk memahami lebih lanjut perkembangan pengaturan tindak pidana di bidang keuangan lihat uraian disertasi mengenai perkembangan pengaturan tindak pidana perbankan (hlm. 326-329), tindak pidana pajak (hlm. 342-344), tindak pidana pasar modal (hlm. 366-370), dan tindak pidana pencucian uang (hlm. 394).
} 
perbankan baru, yang diatur dalam Pasal 48 - Pasal 50 undang-undang tersebut. ${ }^{13}$ Peningkatan kuantitas tindak pidana perbankan juga terjadi melalui perubahan UU Nomor 7 Tahun 1992 dengan UU Nomor 10 Tahun 1998 dimana ada dua perbuatan yang dikriminalisasi oleh pembentuk undang-undang menjadi tindak pidana perbankan baru yang dirumuskan dalam Pasal 47A dan Pasal 50A.

Selanjutnya, peningkatan jumlah tindak pidana di bidang keuangan juga terjadi melalui perubahan UU Pajak. Dalam UU Nomor 6 Tahun 1983 Tentang Ketentuan Umum dan Tata Cara Perpajakan hanya ada 10 jenis tindak pidana pajak yang dirumuskan dalam Pasal 38 sampai dengan Pasal 43. Sedangkan dalam UU Nomor 9 Tahun 1994 tentang Perubahan Undang-Undang Nomor 6 Tahun 1983 ada 2 perbuatan yang dikriminalisasi menjadi tindak pidana pajak baru yang dirumuskan dalam Pasal 41A dan dan 41B sehingga ada 12 jenis tindak pidana pajak.

Akhirnya, peningkatan jumlah tindak pidana di bidang keuangan terjadi melalui perubahan UU Bursa (Pasar Modal) Dalam UU Nomor 5 Tahun 1952 tentang Bursa hanya ada 2 tindak pidana pasar modal (bursa), namun dalam UU Nomor 8 Tahun 1995 tentang Pasar Modal, pengganti UU Bursa, terdapat 21 jenis tindak pidana pasar modal baru yang diatur dalam Pasal 103 sampai dengan Pasal 109.

Peningkatan kuantitas tindak pidana di bidang keuangan dipengaruhi oleh perubahan sosial. Karena hukum bersifat reaktif terhadap perubahan sosial, maka perubahan hukum merupakan respon terhadap perubahan sosial. Peerubahan sosial sebagai penyebab perubahan hukum. Peningkatan kuantitas tindak pidana di bidang keuangan dipengaruhi oleh teknologi. Banyak sosiolog dan ahli hukum yang berpendapat bahwa teknologi adalah salah satu kekuatan penggerak yang sangat besar bagi perubahan hukum. ${ }^{14}$

Di samping itu, peningkatan kuantitas perumusan tindak pidana di bidang keuangan juga dipengaruhi oleh kecenderungan globalisasi di bidang ekonomi dan perdagangan. Globalisasi berarti perluasan skala, penambahan besaran, dan peningkatan dampak aliran dan pola interaksi sosial melewati batas-batas benua. Globalisasi juga berarti pergeseran atau transformasi pada skala organisasi manusia

${ }^{13}$ Dalam satu Pasal ada yang memuat satu jenis tindak pidana, namun ada juga yang memuat sampai 3 jenis tindak pidana. Bahkan ada Pasal yang tidak memuat substansi tindak pidana, kecuali penjelasan mengenai klasifikasi delik yang sudah diatur sebelumnya.

${ }^{14}$ Steven Vago, mengutip Stover dalam Law And Society, Third edition, 1991, hlm. 216. 
yang menghubungkan komunitas-komunitas yang berjauhan dan memperluas jangkauan hubungan kekuasaan lintas wilayah dan benua. ${ }^{15}$

\section{b. Dasar Pembenaran Kriminalisasi}

Dasar pembenaran mengkriminalisasi perbuatan-perbuatan yang berkaitan dengan aktivitas di bidang keuangan: aktivitas di bidang perbankan, aktivitas di bidang pajak, aktivitas di bidang pasar modal dan aktivitas di bidang pencucian uang, menurut pendapat penulis, menggunakan teori liberal individualistik dan teori ordenings strafrecht.

Teori liberal individualistik bertitik tolak dari prinsip kerugian yang merujuk kepada pemikiran John Stuart Mill yang dirumuskan dalam bukunya On Liberty: "The only purpose for which power can be rightfully exercised over any member of civilised society, against his will, is to prevent harm to others. His own good, either physical or moral, is not a sufficient warrant."16

Dasar pembenaran mengkriminalisasi suatu perbuatan sebagai tindak pidana perbankan yang merugikan kepentingan masyarakat berkaitan dengan perbuatan melakukan praktek perbankan tanpa izin, membocorkan rahasia bank, membuat pembukuan yang tidak benar, mengubah, menghilangkan dan menyembunyikan catatan dalam pembukuan.

Sedangkan dasar pembenaran mengkriminalisasi suatu perbuatan sebagai tindak pidana pajak adalah merugikan keuangan negara atau merugikan pendapatan negara dan merugikan masyarakat. Perbuatan merugikan negara misalnya perbuatan wajib pajak yang tidak menyetorkan kewajiban pajaknya kepada negara. Masyarakat menderita kerugian akibat tindak pidana pajak karena pajak adalah instrumen untuk membiayai kepentingan dan pelayanan publik.

Dasar pembenaran menetapkan suatu perbuatan sebagai tindak pidana pasar modal adalah merugikan kepentingan masyarakat. Aktivitas-aktivitas di pasar modal dapat merugikan masyarakat jika para pihak yang terlibat di pasar modal berpraktek secara illegal dan mengungkapkan informasi yang tidak benar dalam perdagangan saham, manipulasi, dan perdagangan orang dalam (insider trading).

Adapun dasar pembenaran mengkriminalisasi suatu perbuatan sebagai tindak pidana pencucian uang adalah merugikan keuangan negara. Negara dirugikan akibat

\footnotetext{
${ }^{15}$ Held, Mc. Grew, David \& Anthony, Globalization/ Anti-Globalization, Oxford, Blackwell, 2003, hlm. 1

${ }^{16}$ John Stuart Mill, On Liberty, 1974, bab 1 paragraf 9.
} 
para pelaku pencucian uang melakukan penghindaran pajak. Dalam konteks mikro ekonomi, dampak dari praktek pencucian uang merugikan nasabah, merugikan konsumen, dan merugikan masyarakat. Dalam kontek sosial, realitas kejahatan pencucian uang yang menghasilkan dana dalam jumlah besar cenderung makin meningkat sangat menimbulkan kerugian bagi masyarakat, bangsa, dan negara,

Dengan terbuktinya penggunaan teori liberal individualistik sebagai dasar pembenaran kriminalisasi bagi berbagai aktivitas di bidang keuangan sebagai tindak pidana berarti pembentukan dan perubahan Undang-Undang di Bidang Keuangan sangat dipengaruhi oleh liberalisme, khususnya sistem ekonomi pasar bebas (free market).

Dalam sistem ekonomi pasar, kekuatan-kekuatan ekonomi, baik besar, menengah, maupun dan kecil, diberi peluang yang sama untuk berkompetisi secara terbuka dan sehat untuk mendapatkan modal dan peluang-peluang ekonomi guna mendapatkan keuntungan yang sebesar-besarnya. Setiap individu diberi kebebasan yang seluas-luasnya untuk mengembangkan potensi ekonomi individualnya guna medapat kekayaan secara maksimal.

Liberalisme yang mendorong berkembangnya individualisme tentu tidak sejalan dengan idiologi Pancasila yang meninginkan berkembangnya sistem ekonomi kekelurgaan, dan sistem sosial masyarakat Indonesia yang cenderung bersifat komunal. Namun paham liberalisme ini hanya sangat berpengaruh dalam pembentukan dan perubahan Undang-Undang Di Bidang Keuangan, tidak di bidang idiologi, kesusilaan dan keagamaan. Pengaruh liberalisme, khususnya sistem ekonomi pasar, terhadap pembentukan dan perubahan Undang-Undang Di Bidang Keuangan adalah wajar karena sistem ekonomi dunia dikuasai oleh ekonomi pasar.

Di samping menggunakan teori liberal individualistik, dasar pembenaran kriminalisasi bagi tindak pidana di bidang keuangan juga menggunakan teori ordenings strafrecht. Indikasi tesis pertama dari teori ordenings strafrecht terlihat dari subjek yang menjadi pelaku tindak pidana di bidang keuangan adalah orang-orang yang mempunyai peranan tertentu dalam berbagai aktivitas tertentu dengan kewajibankewajiban yang harus dijalankannya. Misalnya, direksi, komisaris, dan pegawai bank dan pihak terafiliasi di dalam bidang perbankan. Pelaku kegiatan bursa, pelaku lembaga kliring dan penjaminan, pelaku reksa dana, pelaku perusahaan efek, penasehat investasi, kustodian, biro administrasi efek, wali amanat, dan profesi penunjang pasar modal. Sedangkan dalam kegiatan perpajakan, pemegang peran tersebut adalah 
aparatur pajak. Adapun dalam bidang pencucian uang meliputi pejabat atau pegawai PPATK, penyidik, penuntut umum, hakim, pejabat atau penyedia jasa keuangan.

Indikasi tesis kedua teridentifikasi dari rancangan tindak pidana yang diatur dalam rancangan undang-undang di bidang keuangan yang kemudian dikriminalisasi menjadi tindak pidana merupakan usulan dari pemerintah. Dengan demikian, perbuatan-perbuatan yang dikriminalisasi adalah perbuatan-perbuatan yang sesuai dengan kebijakan dan kehendak pemerintah. Sedangkan indikasi tesis ketiga tergambar dari kebijakan pembentukan Undang-Undang di Bidang Keuangan yang menempatkan undang-undang sebagai instrumen ekonomi untuk mencapai berbagai tujuan di bidang ekonomi dan keuangan.

Dengan demikian, teori liberal individualistik dan teori ordenings strafrecht terbukti digunakan sebagai dasar pembenaran untuk mengkriminalisasi berbagai aktivitas di bidang keuangan sebagai tindak pidana yang diancam dengan sanksi pidana tertentu.

Diskursus pemikiran mengenai pengaturan tindak pidana menunjukkan adanya diskusi di kalangan pembentuk undang-undang dalam menetapkan suatu perbuatan sebagai tindak pidana, tapi penetapan suatu perbuatan sebagai tindak pidana tidak didukung dengan data empiris, khususnya mengenai tingkat kerugian yang ditimbulkan tindak pidana tersebut. Bagi undang-undang baru yang dibuat, jenis tindak pidana yang dikriminalisasi diadopsi dari undang-undang asing.

Kebijakan pembentuk undang-undang mengkriminalisasi berbagai aktivitas di bidang keuangan sebagai tindak pidana dimaksudkan untuk melindungi berbagai kepentingan yang terdapat dalam masyarakat. Perlindungan tersebut meliputi perlindungan kepentingan negara, perlindungan kepentingan masyarakat, perlindungan kepentingan kelompok masyarakat, perlindungan kepentingan institusi keuangan, dan perlindungan kepentingan aparatur yang bekerja di sektor keuangan.

\section{c. Kebijakan Pengaturan Sanksi Pidana Bagi Tindak Pidana Di Bidang Keuangan}

Jenis sanksi pidana yang diancamkan terhadap tindak pidana di bidang keuangan yang diteliti penulis adalah sanksi pidana pokok yang terdiri dari pidana kurungan, pidana penjara, dan pidana denda. ${ }^{17}$ Sanksi pidana yang diancamkan

${ }^{17}$ Untuk memahami lebih lanjut mengenai jenis dan gradasi sanksi pidana bagi tindak pidana di bidang keuangan, lihat uraian disertasi mengenai jenis dan gradasi sanksi pidana bagi tindak pidana perbankan (hlm. 444449), tindak pidana pajak (hlm. 490-499), tindak pidana pasar modal (hlm. 520-526), dan tindak pidana pencucian uang (hlm. 545-555). 
terhadap tindak pidana di bidang keuangan semuanya berbentuk sanksi ganda, yaitu penggabungan pidana penjara dengan pidana denda atau penggabungan pidana kurungan dengan pidana denda, kecuali untuk 3 (tiga) jenis tindak pidana pencucian uang yang diatur dalam Pasal 8, Pasal 9 dan Pasal 20 UU Nomor 15 Tahun 2002 sebagaimana diubah dengan UU Nomor 25 Tahun 2003 tentang Tindak Pidana Pencucian Uang. Sanksi pidana dalam ketentuan tersebut hanya berupa sanksi pidana penjara atau hanya berbentuk sanksi pidana denda.

Kebijakan mengenai pengaturan sanksi pidana bagi tindak pidana di bidang keuangan berkaitan pula dengan pemberatan sanksi pidana bagi tindak pidana di bidang keuangan. Hasil penelitian mengenai hal itu menggambarkan bahwa ada kecenderungan pemberatan sanksi pidana yang diancamkan terhadap tindak pidana di bidang keuangan, ${ }^{18}$ kecuali untuk tindak pidana pencucian uang.

Pengaturan sanksi pidana bagi tindak pidana pencucian uang menggambarkan bahwa sanksi pidana yang dirancang pemerintah untuk tindak pidana pencucian uang diperberat oleh DPR, khususnya untuk pidana denda. Namun dalam perubahan Undang-Undang Nomor 15 Tahun 2002 sanksi pidana denda minimal kemudian diperingan oleh pembentuk undang-undang.

Pemberatan sanksi pidana bagi tindak pidana perbankan dilakukan sebanyak dua kali, yaitu melalui penggantian UU Nomor 14 Tahun 1967 dengan UU Nomor 7 Tahun 1992 tentang Perbankan, dan perubahan UU Nomor 7 Tahun 1992 dengan UU Nomor 10 Tahun 1998. Pemberatan sanksi pidana dalam penggantian UU Nomor 14 Tahun 1967 dengan UU Nomor 7 Tahun 1992 meliputi peningkatan kuantitas lamanya sanksi pidana penjara, peningkatan kuantitas banyaknya pidana denda, dan perubahan sifat penggabungan dua sanksi pidana dari sanksi pidana bersifat alternatif menjadi sanksi pidana bersifat komulatif. Sedangkan pemberatan sanksi pidana melalui perubahan UU Nomor 7 Tahun 1992 menjadi UU Nomor 10 Tahun 1998 meliputi peningkatan sanksi pidana denda dan penetapan sanksi pidana minimum khusus bagi sebagian besar tindak pidana perbankan.

Sedangkan pemberatan sanksi pidana bagi tindak pidana pajak dilakukan satu kali melalui perubahan UU Nomor 6 Tahun 1983 tentang Ketentuan Umum Dan Tata Cara Perpajakan dengan UU Nomor 9 Tahun 1994. Pemberatan sanksi pidana

\footnotetext{
${ }^{18}$ Untuk memahami lebih lanjut mengenai pemberatan sanksi pidana bagi tindak pidana di bidang keuangan, lihat uraian disertasi mengenai pemberatan sanksi pidana bagi tindak pidana perbankan (hlm. 459-469), tindak pidana pajak (hlm. 344-347), tindak pidana pasar modal (hlm. 526-530), dan tindak pidana pencucian uang (hlm. 556-565).
} 
tersebut meliputi pemberatan sanksi pidana penjara, sanksi pidana kurungan dan sanksi pidana denda serta perubahan sifat penggabungan dua sanksi pidana dari bersifat alternatif menjadi bersifat komulatif.

Adapun lingkup pemberatan sanksi pidana bagi tindak pidana pasar modal sama dengan cakupan pemberatan sanksi pidana bagi tindak pidana pajak. Pemberatan sanksi pidana bagi tindak pidana pasar modal dilakukan melalui penggantian UU Nomor 15 Tahun 1952 tentang Bursa dengan UU Nomor 8 Tahun 1995 tentang Pasar Modal, yakni pemberatan sanksi pidana penjara, sanksi pidana kurungan dan sanksi pidana denda serta perubahan sifat penggabungan dua sanksi pidana dari bersifat alternatif menjadi bersifat komulatif.

Dibandingkan dengan sanksi pidana yang diancam terhadap tindak pidana lain, sanksi pidana yang diancam terhadap tindak perbankan yang diatur dalam UU Nomor 10 Tahun 1998 merupakan sanksi pidana yang sangat berat. Penggunaan sanksi pidana bagi tindak pidana perbankan yang diatur dalam UU Nomor 10 Tahun 1998 dapat dikualifikasikan sebagai penggunaan sanksi pidana yang sangat berlebihan (overpenalization) karena: (i) menggunakan sanksi pidana penjara yang sangat berat, (ii) sanksi pidana denda yang sangat banyak dan (iii), penggabungan kedua sanksi tersebut secara komulatif, serta (iv) penggunaan sanksi minimum khusus.

Ide pemberatan sanksi pidana berasal dari pemerintah dan DPR, tapi DPR memiliki inisiatif pemberatan sanksi pidana yang lebih banyak daripada pemerintah. Di samping itu, DPR memiliki semangat memperberat sanksi pidana yang lebih tinggi daripada pemerintah dan karena itu DPR punya andil lebih besar dalam pemberatan sanksi pidana bagi tindak pidana di bidang keuangan.

Kecenderungan pemberatan sanksi pidana bagi tindak pidana di bidang merupakan respon pembentuk undang-undang terhadap kondisi sosial yang ada di masyarakat, khususnya lemahnya penegakan hukum, dan upaya untuk merekayasa pembaruan di dalam institusi keuangan. Di sampng itu, kecenderungan pemberatan sanksi pidana juga merupakan implementasi penggunaan falsafah pemidanaan penangkalan dalam pengaturan sanksi pidana dan "spirit" menghukum (punitive spirit) penjahat yang sangat besar di kalangan pembentuk undang-undang.

Pemberatan sanksi pidana bukan obat yang mujarab untuk mengatasi kelemahan penegakan hukum karena kelemahan penegakan bukan karena sanksi pidana yang rendah, tapi karena kualitas aparat penegak hukum yang rendah dan budaya korupsi yang melanda dunia peradilan. Adanya spirit menghukum yang sangat berat di 
kalangan pembentuk undang-undang karena adanya keyakinan di antara mereka bahwa penetapan sanksi pidana berat otomatis mempunyai dampak psikologis terhadap orang yang mengetahui sanksi pidana tersebut.

\section{d. Penggunaan Falsafah Pemidanaan}

Kebijakan pengaturan sanksi pidana bagi tindak pidana di bidang keuangan juga berkaitan dengan falsafah pemidanaan yang digunakan sebagai dasar pengaturan sanksi pidana. Dalam kerangka pemikiran dirumuskan bahwa falsafah pemidanaan yang digunakan dalam pengaturan sanksi pidana bagi tindak pidana di bidang keuangan adalah falsafah pemidanaan penangkalan yang di kombinasikan dengan prinsip proporsionalitas kardinal dan prinsip proporsionalitas ordinal dari teori retribusi. ${ }^{19}$

Hasil penelitian yang dilakukan mengindikasikan falsafah pemidanaan yang digunakan pembentuk undang-undang dalam pengaturan sanksi pidana bagi tindak pidana di bidang keuangan adalah falsafah pemidanaan penangkalan, meskipun tidak semua tesis pokok falsafah pemidanaan tersebut terpenuhi.

Penggunaan falsafah pemidanaan penangkalan dalam pengaturan sanksi pidana bagi tindak pidana di bidang keuangan memiliki indikasi paling jelas dalam pengaturan sanksi pidana bagi tindak pidana pajak yang diatur UU Nomor 9 Tahun 1994 dan sanksi pidana bagi tindak pidana pasar modal yang diatur UU Nomor 8 Tahun 1995.

Ada tiga indikasi penggunaan falsafah pemidanaan penangkalan dalam pengaturan sanksi pidana pajak, yaitu: (i) penggunaan istilah “deterrence" - yang merupakan istilah baku falsafah pemidanaan penangkalan, (ii) penetapan sanksi pidana denda bagi tindak pidana pajak yang lebih besar daripada nilai kerugian yang ditimbulkan tindak pidana tersebut. Denda itu bisa dua kali lipat atau empat kali lipat dari kerugian yang ditimbulkan tindak pidana tersebut, (iii) fungsi sanksi pidana yang diancamkan terhadap tindak pidana perpajakan adalah untuk mencegah orang melakukan tindak pidana pajak atau membuat pelaku tindak pidana pajak tidak mengulangi melakukan tindak pidana.

\footnotetext{
${ }^{19}$ Untuk memahami lebih lanjut mengenai falsafah pemidanaan sebagai dasar pengaturan sanksi pidana, lihat uraian disertasi mengenai falsafah pemidanaan dalam pengaturan sanksi pidana bagi tindak pidana perbankan (hlm. 480-490), tindak pidana pajak (hlm. 514-520), tindak pidana pasar modal (hlm. 541-545), dan tindak pidana pencucian uang (hlm. 565-569).
} 
Sedangkan indikasi penggunaan falsafah pemidanaan penangkalan dalam pengaturan sanksi pidana bagi tindak pidana pasar modal ada 3, yaitu: (i) pendapat pembentuk undang-undang yang menyatakan bahwa orang-orang yang terlibat dalam pasar modal adalah orang terpelajar yang rasional yang dengan adanya sanksi pidana dapat mengendalikan diri agar tidak melanggar undang-undang, (ii) sanksi pidana berfungsi sebagai alat untuk menakut-nakuti para pelaku dan calon-calon pelaku tindak pidana pasar modal. (iii) tujuan pemidanaan adalah untuk memberi efek jera dan menangkal orang supaya tidak melakukan tindak pidana karena ada ancaman sanksi yang berat.

Dalam UU Perbankan, indikasi penggunaan falsafah pemidanaan penangkalan tergambar dari besaran sanksi pidana dan fungsi sanksi pidana. Sanksi pidana yang diancamkan terhadap perbuatan mendirikan bank tanpa izin adalah pidana penjara sekurang-kurangnya 5 tahun dan selama-lamanya 15 tahun dan denda sekurangkurangnya 10 milyar rupiah dan sebanyak-banyaknya 200 milyar rupiah. Fungsi sanksi pidana adalah untuk mencegah terjadinya tindak pidana perbankan.

Adapun pengaturan sanksi pidana bagi tindak pidana pencucian uang yang diatur dalam UU Nomor 15 Tahun 2002 yang diubah menjadi UU Nomor 25 Tahun 2003 juga menggunakan falsafah pemidanaan penangkalan. Indikasi penggunaan falsafah pemidanaan penangkalan terdiri dari pendapat pembentuk undang-undang yang menyatakan bahwa dasar pengaturan sanksi pidana bagi tindak pidana pencucian uang adalah falsafah pemidanaan penangkalan, Sanksi pidana yang relatif berat yang diancamkan terhadap tindak pidana pencucian uang, dan fungsi sanksi pidana ditetapkan dengan tujuan agar terdapat efek penjeraan bagi para pelakunya dan para pihak yang berpotensi untuk melakukan pencucian uang.

Pembahasan tentang teori penangkalan seringkali membuat kita terjebak pada perangkap absolutisme: karena semua perilaku tidak bisa dicegah dengan hukuman, maka hukuman tidak akan bisa mencegah kejahatan. Tapi “untuk membenarkan pemberian hukuman, tidak perlu membuktikan bahwa pemberian hukuman pasti bisa mencegah kejahatan dengan sifat pencegahannya. Cukuplah kita mengindikasikan bahwa akan semakin banyak kejahatan bila semua hukuman dihapuskan. ${ }^{20}$

Pembentuk UU di Bidang Keuangan dalam menentukan sanksi pidana bagi tindak pidana di bidang keuangan terutama bertitik tolak dari asumsi teori

${ }^{20}$ Michael J. Allen, Criminal Law, Edisi Kelima, London, Blackstone Press Limited, 1999, hlm. 6. 
penangkalan kedua bahwa hukuman yang berat mencegah orang melakukan kejahatan, namun dalam pengertian yang lebih sederhana. Sanksi pidana yang berat dinilai secara otomatis memberi dampak psikologis bagi setiap orang yang mengetahuinya, padahal efektivitas falsafah pemidanaan penangkalan tidak terletak pada beratnya hukuman, tapi pada implementasi sanksi pidana tersebut dalam sistem peradilan pidana. Misalnya, probabilitas penangkapan, penahanan, penuntutan, dan penjaruhan hukuman.

Pembentuk undng-undang tidak mempertimbangkan dampak negatif jika sanksi pidana berat yang diancamkan terhadap tindak pidana di bidang keuangan tidak ditegakkan sebagaimana mestinya. Sanksi pidana yang berat yang tidak ditegakkan dapat mempunyai dampak negatif terhadap hukum pidana dan sistem peradilan pidana, dan doktrin ilmu hukum pidana.

Dalam pengaturan sanksi pidana, prinsip proporsionalitas cardinal, yaitu tingkat skala hukuman, hukuman maksimum dan jarak huluman nyata harus proporsional terhadap besarnya serangan dari perbuatan yang dilarang, digunakan pembentuk undang-undang dalam menentukan berat ringannya sanksi pidana, meskipun dalam diskursus pemikiran tentang pengaturan sanksi pidana tidak selalu muncul. Hal ini secara umum (terdapat pada semua undang-undang) terlihat dari pembedaan tindak pidana dalam kealpaan dan kesengajaan dan pembedaan tindak pidana antara tindak pidana kelompok pelanggaran dan tindak pidana kelompok kejahatan.

Di samping itu, penggunaan proporsionalitas cardinal juga terlihat secara spesifik dalam masing-masing undang. Misalnya, dalam tindak pidana pasar modal, semakin penting peranan seorang aktor dalam aktivitas pasar modal, maka semakin berat sanksi hukuman yang akan diterimanya jika ia melanggar kewajiban hukumnya.

Sedangkan prinsip proposionalitas ordinal, memperhatikan berapa suatu kejahatan harus dihukum diperbandingkan dengan tindak pidana yang mirip, dan diperbandingkan terhadap karakter lebih atau kurang serius dari kejahatan lain, digunakan secara terbatas oleh pembentuk undang-undang. Artinya, prinsip tersebut hanya digunakan ketika membahas tindak pidana tertentu, misalnya, pengungkapan rahasia di bidang keuangan dan melakukan aktivitas bisnis di bidang keuangan tanpa izin. 


\section{Penutup}

Kebijakan pengaturan tindak pidana menunjukkan peningkatan perbuatan yang dikriminalisasi oleh pembentuk undang-undang sebagai akibat perubahan sosial, globalisasi ekonomi dan perdagangan, dan perkembangan teknologi. Dasar pembenaran mengkriminalisasi berbagai aktivitas di bidang keuangan bukan hanya karena perbuatan tersebut merugikan negara dan atau masyarakat (teori liberal individualistik), tapi juga karena perbuatan tersebut bertentangan dengan kebijakan pemerintah di bidang ekonomi (teori ordenings strafrecht).

Kebijakan pengaturan sanksi pidana menunjukkan adanya kecenderungan pemberatan sanksi pidana bagi tindak pidana di bidang keuangan sebagai respon terhadap lemahnya penegakan hukum, upaya mengubah kondisi institusi keuangan, implementasi falsafah pemidanaan penangkalan dan "spirit" menghukum penjahat yang sangat besar di kalangan pembentuk undang-undang. Falsafah pemidanaan yang digunakan dalam pengaturan sanksi pidana adalah falsafah pemidanaan penangkalan yang digabungkan dengan prinsip proporsionalitas kardinal dan prinsip proporsionalitas ordinal.

\section{Saran}

1. Pengaturan sanksi pidana denda bagi tindak pidana di bidang keuangan, jika menggunakan falsafah pemidanaan penangkalan, seharusnya dirumuskan seperti pengaturan sanksi pidana denda bagi tindak pidana pajak yang menetapkan sanksi denda beberapa kali lipat dari kerugian yang ditimbulkan oleh tindak pidana.

2. Pembentuk undang-undang harus berhati-hati menggunakan hukum pidana dan sanksi pidana guna menegakkan norma hukum pidana karena penggunaan hukum pidana dan sanksi yang berlebihan dapat menimbulkan dampak negatif terhadap hukum pidana (inflasi pidana dan pelampauan batas penggunaan hukum pidana) dan penegakan hukum pidana. 


\section{Daftar Pustaka}

Allen, Francis, dalam Sue Titus Reid, Crime and Criminology, second edition, Holt, Rinehart and Wington, 1979.

Anthony, Held, Mc. Grew, David \&, Globalization / Anti-Globalization, Oxford, Blackwell, 2003.

Arief Barda Nawawi Bunga Rampai Kebijakan Hukum Pidana, Bandung, Citra Aditya Bhakti, 1996.

Ashworth, Andrew, Principles of Criminal Law, Oxford, Clarendon Press, 1991

Beccaria, Of Crimes and Punishments, New York, Marsilio Publishers, Corp., 1996.

C. Gibbon, Don, Society, Crime, and Crimnal Careers, Third edition, Englewood Prentice Hall Inc., 1973.

Clarkson, C.M.V, Understanding Criminal Law, Second Edition, London, Suveet and Maxwell, 1998.

Duff, R.A, "Symposium The Moral Limit of The Criminal Law: Harms and Wrongs", Law Review and Journal Criminal Law Review Article, 4 Januari 2003.

D. Pursley, Robert, Introduction to Criminal Justice, Macmillan Publishing Company New York, Collier Macmillan Publishers London, 1987.

Epstein, Richard A., "Symposium: The Tort/Crime Distinction: A Generation Later", diakses melalui, Lexis-Nexis.com., 19 Desember 2002.

E. Conklin, John, Criminology, Second Edition, Mac Millan Publishing Company, New York, 1986.

Feinberg, Joel, Fiends and Slime Harm To Others, New York, Oxford University Press, 1984.

Held, Mc. Grew, David \& Anthony, Globalization / Anti-Globalization, Oxford, Blackwell, 2003.

J. Allen, Michael, Criminal Law, Edisi Kelima, London, Blackstone Press Limited, 1999.

Salman Luthan, "Kebijakan LegislatifMengenai Kriminalisasi dalam Perundang-undangan Pidana", Tesis S2, UI, Jakarta, 1998.

Mill, John Stuart, On Liberty, 1974.

Mardjono Reksodiputro, "Catatan-Catatan Sekilas Tentang Bab Pemidanaan, Pidana dan Tindakan (Bab III - Buku Kesatu)", Rancangan Undang-Undang Republik Indonesia Tentang KUHP.

Rusli Effendi, dkk, "Masalah Kriminalisasi dan Dekriminalisasi dalam Rangka Pembaruan Hukum Nasional" dalam BPHN, Simposium Pembaruan Hukum Pidana Nasional Indonesia, Jakarta, Binacipta. 1986. 
Soerjono Soekanto, dan Sri Mamudji, Penelitian Hukum Normatif, Cetakan ketujuh, Jakarta, PT Raja Grafindo Persada, 2003.

Vago, Steven, Law And Society, Third edition, 1991. 